\title{
Free-association norms for the Spanish names of the Snodgrass and Vanderwart pictures
}

\author{
ANGEL FERNANDEZ and EMILIANO DIEZ \\ Universidad de Salamanca, Salamanca, Spain \\ MARÍA ANGELES ALONSO \\ Universidad de La Laguna, La Laguna, Tenerife, Spain \\ and \\ MARÍA SOLEDAD BEATO \\ Universidad de Salamanca, Salamanca, Spain
}

\begin{abstract}
The most frequent names in Spanish corresponding to a set of 247 pictures in the Snodgrass and Vanderwart (1980) norms were used as stimuli in a discrete free-association task. A sample of 525 Spanishspeaking participants provided the first word that came to mind for each of the verbal stimuli. Responses were organized according to frequency of production in order to prepare word-association norms for the set of stimuli.
\end{abstract}

The questions addressed in cognitive psychology experiments often require the selection of linguistic and pictorial materials with specific objectively or subjectively determined characteristics. One way in which material selection can be adequately accomplished is by using indices empirically obtained in normative studies.

Free-association norms are among the most frequently used normative data in cognitive research. The production frequency of a particular word as a free-association response to another word used as a stimulus is usually taken as an indication of the strength of the connection between the representations of the two words in memory (see Nelson, McEvoy, \& Dennis, 2000, for a discussion on how to interpret free-association indices). Manipulations of the strength of these connections using the values provided in free-association norms have been proven to reliably affect semantic facilitation in priming studies (Meyer \& Schvaneveldt, 1971), level of performance in free recall (Deese, 1959) and in cued recall (Nelson, McKinney, Gee, \& Janczura, 1998), and false recall and false recognition of unstudied words (Roediger \& McDermott, 1995), to name a few examples.

Free-association norms for English words have been available for several decades, starting with the widely used

This work was supported by two Spanish funding agencies: Ministerio de Ciencia y Tecnología (Project BSO2001-1850) and Junta de Castilla y León (Project SA049/03). The authors thank María Jesús Sánchez and Natividad Rodríguez for their contributions to data collection and database management, respectively. Thanks are also due the Editor (Jonathan Vaughan) and two reviewers (Roberto Dell'Acqua and Douglas Nelson) for very helpful comments and suggestions on the first version of the manuscript. Correspondence concerning this article should be addressed to A. Fernandez, Facultad de Psicología, Universidad de Salamanca, E-37071 Salamanca, Spain (e-mail: angelfr@usal.es). norms for 100 words published by Russell and Jenkins (1954). Normative studies of this kind have continued to be regularly published (see Proctor \& Vu, 1999, for a comprehensive listing), and currently there is an electronic database that provides norms for more than 5,000 words (Nelson, McEvoy, \& Schreiber, in press). With regard to the Spanish language, the availability of this type of normative data is highly restricted. In the only published study, Macizo, Gómez-Ariza, and Bajo (2000) recently provided associative data for 52 words, but their sample included only children between 8 and 13 years of age. Freeassociation norms for adults were compiled by Algarabel, Sanmartín, García, and Espert (1986), but their database, although used by some researchers, has never been formally published or widely distributed.

Given the scarcity of associative indices for words in Spanish, the main goal of the present study was to construct a free-association normative database based on the responses of a relatively large sample of Spanish-speaking adults to a set of words, which could be of interest to a variety of cognitive researches in our linguistic community.

A set of materials for which there already exist data on a number of defining characteristics in Spanish consists of the pictorial stimuli originally normed by Snodgrass and Vanderwart (1980) for English speakers. Following this influential study, the pictures have been standardized in the basic dimensions of name agreement, image agreement, familiarity, and visual complexity in independent studies with adult samples in Spain (Sanfeliu \& Fernandez, 1996), Mexico (Aveleyra, Gómez, Ostrosky, \& Rigalt, 1996), and Cuba (Manzano, Piñeiro, \& Reigosa, 1997). Other studies using Spanish-speaking subjects have provided additional normative data on this set of stimuli, such as word identification thresholds for fragmented 
names of the pictures (Reales, Ballesteros, \& García, $2002)$ and their naming times and ages of acquisition (Cuetos, Ellis, \& Alvarez, 1999).

Taking into account the wide use of these pictorial materials and the availability of normative data for some of their important dimensions, in this study we decided to use the words that named them as the stimuli in a freeassociation task, with the aim of obtaining associative norms that could add to a more complete characterization of the materials in Spanish as well as provide corresponding norms for a sizable set of common words.

\section{METHOD}

\section{Participants}

A total of 525 undergraduate students at the University of Salamanca and the University of La Laguna, both located in Spain, participated in the experiment in exchange for academic credit. All of them were native speakers of Spanish.

\section{Materials}

The verbal materials used as stimuli in the free-association task were a set of words that, according to Sanfeliu and Fernandez (1996), corresponded to the most frequent denominations in Spanish of the Snodgrass-Vanderwart standardized pictures. Although the norms collected by Sanfeliu and Fernandez include the most frequent names for a total of 254 pictures, a few of these names are actually repeated, because the majority of participants in their study used them to name two different pictures (e.g., the word reloj was the most frequent name assigned to both Picture 60 [clock] and Picture 250 [watch]). For this reason, the final set of stimuli was reduced to 247 different terms, of which 238 were one-word names and 9 were compound names. Table A1 includes a listing of these stimuli, with their corresponding picture numbers and English names from the original norms of Snodgrass and Vanderwart (1980) to facilitate identification.

A five-page booklet was used to collect the responses. On each page, the stimuli were printed in uppercase letters and arranged in two columns, and space was provided to the right of each stimulus for the participants to write their responses. To control for order effects, 10 different versions of the booklet were constructed for later random distribution, each of them with a different randomly determined order of stimuli. A cover sheet in the booklet presented the instructions for the task, as is described below.

\section{Procedure}

The participants performed the task in groups of 20-40 people. They went through the booklets at their own pace, with completion times ranging from 20 to $40 \mathrm{~min}$.

At the beginning of the session, the participants read the printed instructions on the cover sheet of the booklet. In these instructions, they were asked to read, one by one, each of the terms printed on the pages of the booklet and to write, for each name, another word in the corresponding blank space. More specifically, they were instructed to write "the first word that you think of when reading the preprinted term ... the first word that comes to your mind." They were also instructed to work as fast as possible, to go through the stimulus series in order, to write only one word for each stimulus, and to respond to all of them. It was made explicit that there were no correct or incorrect answers. Two examples, in which filler stimuli and responses were used, were presented to further clarify the task.

\section{RESULTS AND DISCUSSION}

A computerized procedure was used to type and literally record each of the individual responses given by the participants. The total number of blank responses was 62 , an insignificant quantity given that the number of required responses totaled 129,675 ( 247 responses $\times 525$ booklets $)$. In a few cases (less than $1 \%$ overall), the handwritten responses were not readily interpretable by any of four independent judges (the authors) and were therefore coded as illegible. Words with unambiguous spelling errors were recoded in their orthographically correct form. Misspelled responses for which more than one valid orthographic correction was possible were coded as illegible.

As is shown by the data included in Table A1, there was a noticeable variability in the number of independent responses evoked by each of the 247 stimuli, which ranged from 39 for the word barril to 163 for the word burro, with a mean of 96.62. Each stimulus evoked a large number of idiosyncratic responses (i.e., those provided by only 1 participant), a reasonable result given the nature of the task and the large number of participants in the study. However, there was also evidence of remarkable agreement and consistency. Each stimulus evoked a limited set of responses that occurred very frequently, as is shown by the fact that, on average, the five most frequent free associates of each stimulus accounted for $50 \%$ of the participants' responses.

Free-association norms for the 247 verbal stimuli are provided in an appendix (see the Archived Materials section). For each stimulus, the norms include a complete listing of the different responses given by the participants, and the proportion of participants who gave each response is stated. These relative frequency values reflect the probability that the response will be produced as an associate when the stimulus is processed and, as was noted in the introduction, they can be taken as stable indicators of the strength of the preexisting connection between the memory representation of the stimulus and that of the response.

Because free-association norms can be significantly determined by linguistic peculiarities and cultural usages, caution should be used in generalizing our results, obtained in Spain, to other Spanish-speaking populations. Nonetheless, taking into consideration this and other generalizability limitations that may impose restrictions when dealing with norms of this kind, the present data set is likely to be useful for the selection, control, and manipulation of verbal materials in psychological experiments with Spanish-speaking participants, especially those that address questions in the areas of memory, language, and related fields. Furthermore, the provided normative data can be used in conjunction with data about other objective and subjective dimensions of the stimuli that are already available. For example, printed frequency information for $95 \%$ of the stimulus words can be found in the frequency dictionary of Alameda and Cuetos (1995); $34 \%$ of the stimuli have empirically obtained indices of concreteness, imageability, familiarity, and pleasantness (Algarabel, 1996); and over $80 \%$ of the stimuli are included as exemplars in the categorical norms of Soto, Sebastián, García, and del Amo (1994). Finally, the freeassociation norms collected in this study contribute to a 
more complete characterization of the verbal stimuli corresponding to the widely used set of pictorial stimuli first developed and standardized by Snodgrass and Vanderwart (1980).

\section{REFERENCES}

Alameda, J. R., \& Cuetos, F. (1995). Diccionario de frecuencias de las unidades lingüísticas del castellano. Oviedo: Servicio de Publicaciones de la Universidad de Oviedo.

Algarabel, S. (1996). Índices de interés psicolingüístico de 1917 palabras castellanas. Cognitiva, 8, 43-88.

Algarabel, S., Sanmartín, J., García, J., \& EsPert, R. (1986). Normas de asociación libre para la investigación experimental. Unpublished manuscript, University of Valencia, Department of Experimental Psychology.

Aveleyra, E., Gómez, C., Ostrosky, F., \& Rigalt, C. (1996). Adaptación de los estímulos no verbales de Snodgrass y Vanderwart en población hispanoparlante: Criterios para la denominación, concordancia de la imagen, familiaridad y complejidad visual. Revista Mexicana de Psicología, 13, 5-19.

Cuetos, F., Ellis, A. W., \& Alvarez, B. (1999). Naming times for the Snodgrass and Vanderwart pictures in Spanish. Behavior Research Methods, Instruments, \& Computers, 31, 650-658.

DeEse, J. (1959). Influence of inter-item associative strength upon immediate free recall. Psychological Reports, 5, 305-312.

Macizo, P., Gómez-Ariza, C. J., \& BaJo, M. T. (2000). Associative norms for 58 Spanish words for children from 8 to 13 years old. Psicológica, 21, 287-300.

Manzano, M., Piñeiro, A., \& Reigosa, V. (1997). Estudio de las características de un conjunto de 260 figuras en sujetos adultos de habla hispana. Cognitiva, 9, 29-64.

Meyer, D. E., \& SchVaneveldt, R. W. (1971). Facilitation in recognizing pairs of words: Evidence of a dependence in retrieval operations. Journal of Experimental Psychology, 90, 227-234.

Nelson, D. L., McEvoy, C. L., \& Dennis, S. (2000). What is free association and what does it measure? Memory \& Cognition, 28, 887899.

Nelson, D. L., McEvoy, C. L., \& Schreiber, T. A. (in press). The University of South Florida word association, rhyme, and word fragment norms. Behavior Research Methods, Instruments, \& Computers.

Nelson, D. L., McKinney, V. M., Gee, N. R., \& Janczura, G. A. (1998). Interpreting the influence of implicitly activated memories on recall and recognition. Psychological Review, 105, 299-324.
Proctor, R. W., \& Vu, K.-P. L. (1999). Index of norms and ratings published in the Psychonomic Society journals. Behavior Research Methods, Instruments, \& Computers, 31, 659-667.

Reales, J. M., Ballesteros, S., \& García, E. (2002). Visual-word identification thresholds for the 260 fragmented words of the Snodgrass and Vanderwart pictures in Spanish. Behavior Research Methods, Instruments, \& Computers, 34, 276-285.

Roediger, H. L., III, \& McDermott, K. B. (1995). Creating false memories: Remembering words not presented in lists. Journal of Experimental Psychology: Learning, Memory, \& Cognition, 21, 803-814.

Russell, W. A., \& Jenkins, J. J. (1954). The complete Minnesota norms for responses to 100 words from the Kent-Rosanoff word association test (Tech. Rep. No. 11, Contract N8-ONR-66216, ONR). Minneapolis: University of Minnesota Press.

Sanfeliu, M. C., \& Fernandez, A. (1996). A set of 254 SnodgrassVanderwart pictures standardized for Spanish: Norms for name agreement, image agreement, familiarity, and visual complexity. Behavior Research Methods, Instruments, \& Computers, 28, 537-555.

SnODGrass, J. G., \& VANDERWART, M. (1980). A standardized set of 260 pictures: Norms for name agreement, image agreement, familiarity, and visual complexity. Journal of Experimental Psychology: Human Learning \& Memory, 6, 174-215.

Soto, P., Sebastián, M. V., García, E., \& del Amo, T. (1994). Las categorías y sus normas en castellano. Madrid: Visor.

\section{ARCHIVED MATERIALS}

The following materials associated with this article may be accessed through the Psychonomic Society's Norms, Stimuli, and Data archive, http://www.psychonomic.org/archive/.

To access these files, search the archive for this article using the journal (Behavior Research Methods, Instruments, \& Computers), the first author's name (Fernandez), and the publication year (2004).

FiLE: Fernandez-BRMIC-2004.zip.

DESCRIPTION: The compressed archive file contains two files:

fernandez2004AppendixA.pdf, containing an alphabetical list of stimuli and summary descriptive information for the responses in a 496page .pdf document.

fernandez2004norms.xls, containing the norms as a 1,960K Microsoft Excel file. Each row represents one of 23,776 free-association responses. There are three columns: word (the stimulus used in the free-association task), response (a verbal response elicited by the stimulus), and proportion (proportion of participants who gave the specific response).

AUTHOR’s E-MAIL ADDRESS: angelfr@usal.es.

\section{APPENDIX}

Table A1

Stimuli and Summary of Descriptive Information for the Responses

\begin{tabular}{|c|c|c|c|c|c|c|}
\hline \multirow[b]{2}{*}{ Spanish Stimulus } & \multirow{2}{*}{$\begin{array}{c}\text { Picture } \\
\text { No. }\end{array}$} & \multirow[b]{2}{*}{ English Name } & \multicolumn{4}{|c|}{ Number of Responses } \\
\hline & & & Independent & Idiosyncratic & Blank & Illegible \\
\hline ABEJA & 23 & BEE & 63 & 31 & 0 & 2 \\
\hline ABRIGO & 64 & COAT & 72 & 52 & 1 & 3 \\
\hline ACELGAS & 51 & CELERY & 94 & 56 & 0 & 0 \\
\hline ACORDEÓN & 1 & ACCORDION & 126 & 87 & 0 & 4 \\
\hline ÁGUILA & 82 & EAGLE & 132 & 78 & 0 & 5 \\
\hline AGUJA & 154 & NEEDLE & 76 & 56 & 0 & 0 \\
\hline ALCACHOFA & 9 & ARTICHOKE & 141 & 90 & 1 & 5 \\
\hline ALICATES & 176 & PLIERS & 130 & 75 & 1 & 6 \\
\hline ANCLA & 4 & ANCHOR & 57 & 38 & 0 & 3 \\
\hline ANILLO & 187 & RING & 57 & 34 & 0 & 1 \\
\hline ARAÑA & 212 & SPIDER & 137 & 97 & 3 & 13 \\
\hline ÁRBOL & 241 & TREE & 108 & 58 & 0 & 2 \\
\hline ARDILLA & 216 & SQUIRREL & 111 & 64 & 0 & 1 \\
\hline ARPA & 117 & HARP & 111 & 69 & 0 & 6 \\
\hline AUTOBÚS & 39 & BUS & 135 & 84 & 0 & 5 \\
\hline
\end{tabular}


APPENDIX (Continued)

\begin{tabular}{|c|c|c|c|c|c|c|}
\hline \multirow[b]{2}{*}{ Spanish Stimulus } & \multirow{2}{*}{$\begin{array}{l}\text { Picture } \\
\text { No. }\end{array}$} & \multirow[b]{2}{*}{ English Name } & \multicolumn{4}{|c|}{ Number of Responses } \\
\hline & & & Independent & Idiosyncratic & Blank & Illegible \\
\hline AVESTRUZ & 159 & OSTRICH & 123 & 73 & 1 & 3 \\
\hline AVIÓN & 2 & AIRPLANE & 104 & 66 & 0 & 1 \\
\hline BALÓN DE RUGBY & 95 & FOOTBALL & 116 & 70 & 1 & 8 \\
\hline BANDERA & 90 & FLAG & 94 & 57 & 0 & 1 \\
\hline BARCO & 193 & SAILBOAT & 92 & 59 & 0 & 5 \\
\hline BARRIL & 18 & BARREL & 39 & 24 & 0 & 0 \\
\hline BATE & 19 & BASEBALL BAT & 58 & 37 & 2 & 4 \\
\hline BICICLETA & 27 & BICYCLE & 123 & 73 & 0 & 4 \\
\hline BOLÍGRAFO & 167 & PEN & 54 & 27 & 0 & 4 \\
\hline BOLSO & 178 & POСКETBOOK & 140 & 82 & 2 & 4 \\
\hline BOMBILLA & 138 & LIGHT BULB & 44 & 27 & 0 & 0 \\
\hline ВОТА & 31 & воОт & 105 & 60 & 0 & 4 \\
\hline BOTELLA & 32 & BOTTLE & 75 & 40 & 0 & 1 \\
\hline BOTÓN & 41 & BUTTON & 94 & 58 & 0 & 9 \\
\hline BRAZO & 7 & ARM & 109 & 64 & 0 & 3 \\
\hline ВÚHO & 160 & OWL & 70 & 46 & 0 & 2 \\
\hline BURRO & 75 & DONKEY & 163 & 116 & 0 & 5 \\
\hline CABALLITO DE MAR & 200 & SEA HORSE & 161 & 99 & 0 & 1 \\
\hline CABALLO & 121 & HORSE & 153 & 88 & 0 & 4 \\
\hline CABRA & 107 & GOAT & 83 & 51 & 0 & 3 \\
\hline CACAHUETE & 165 & PEANUT & 106 & 60 & 0 & 2 \\
\hline CADENA & 52 & CHAIN & 137 & 83 & 0 & 3 \\
\hline CAJA & 35 & BOX & 135 & 81 & 0 & 3 \\
\hline CALABAZA & 181 & PUMPKIN & 99 & 57 & 0 & 8 \\
\hline CALCETÍN & 211 & SOCK & 103 & 62 & 0 & 1 \\
\hline CAMA & 22 & BED & 79 & 47 & 0 & 1 \\
\hline CAMELLO & 43 & CAMEL & 72 & 42 & 0 & 1 \\
\hline CAMIÓN & 242 & TRUCK & 140 & 91 & 0 & 8 \\
\hline CAMISA & 203 & SHIRT & 122 & 59 & 0 & 2 \\
\hline CAMPANA & 26 & BELL & 94 & 56 & 0 & 6 \\
\hline CANDADO & 143 & LOCK & 78 & 50 & 0 & 1 \\
\hline CANGREJO & 142 & LOBSTER & 107 & 73 & 0 & 8 \\
\hline CANGURO & 126 & KANGAROO & 69 & 44 & 0 & 5 \\
\hline CARACOL & 208 & SNAIL & 108 & 64 & 0 & 5 \\
\hline CARRITO & 249 & WAGON & 59 & 32 & 0 & 3 \\
\hline CASA & 122 & HOUSE & 127 & 74 & 0 & 3 \\
\hline CASCO & 96 & FOOTBALL HELMET & 84 & 50 & 0 & 3 \\
\hline CAZO & 179 & РОТ & 87 & 50 & 1 & 2 \\
\hline CEBOLLA & 157 & ONION & 76 & 44 & 0 & 4 \\
\hline CENICERO & 10 & ASHTRAY & 61 & 42 & 1 & 1 \\
\hline CEPILLO & 38 & BRUSH & 59 & 40 & 0 & 0 \\
\hline CEPILLO DE DIENTES & 237 & TOOTHBRUSH & 79 & 46 & 0 & 0 \\
\hline CERDO & 172 & PIG & 117 & 74 & 0 & 7 \\
\hline CEREZA & 54 & CHERRY & 119 & 70 & 1 & 3 \\
\hline CESTA & 20 & BASKET & 84 & 51 & 0 & 1 \\
\hline CIERVO & 71 & DEER & 123 & 82 & 0 & 6 \\
\hline CIGARRO & 59 & CIGARETTE & 87 & 53 & 0 & 0 \\
\hline CINTURÓN & 25 & BELT & 80 & 45 & 0 & 1 \\
\hline CISNE & 223 & SWAN & 85 & 52 & 0 & 4 \\
\hline CLAVO & 151 & NAIL & 91 & 57 & 0 & 3 \\
\hline COCINA & 219 & STOVE & 120 & 69 & 0 & 6 \\
\hline COCODRILO & 3 & ALLIGATOR & 104 & 58 & 0 & 2 \\
\hline COCHE & 47 & CAR & 148 & 76 & 0 & 5 \\
\hline COCHECITO & 13 & BABY CARRIAGE & 68 & 47 & 0 & 1 \\
\hline COLUMPIO & 225 & SWING & 85 & 49 & 0 & 4 \\
\hline COLLAR & 153 & NECKLACE & 73 & 40 & 0 & 3 \\
\hline COMETA & 129 & KITE & 100 & 60 & 0 & 1 \\
\hline CÓMODA & 79 & DRESSER & 148 & 83 & 0 & 0 \\
\hline CONEJO & 182 & RABBIT & 150 & 85 & 1 & 10 \\
\hline COPA & 258 & WINEGLASS & 92 & 51 & 0 & 0 \\
\hline CORAZÓN & 119 & HEART & 114 & 71 & 0 & 3 \\
\hline CORBATA & 232 & TIE & 131 & 91 & 0 & 9 \\
\hline CORONA & 69 & CROWN & 66 & 42 & 0 & 2 \\
\hline CUBO DE BASURA & 102 & GARBAGE CAN & 96 & 54 & 0 & 3 \\
\hline CUCARACHA & 24 & BEETLE & 128 & 82 & 0 & 3 \\
\hline CUCHARA & 215 & SPOON & 64 & 33 & 2 & 3 \\
\hline
\end{tabular}


APPENDIX (Continued)

\begin{tabular}{|c|c|c|c|c|c|c|}
\hline \multirow[b]{2}{*}{ Spanish Stimulus } & \multirow{2}{*}{$\begin{array}{c}\text { Picture } \\
\text { No. }\end{array}$} & \multirow[b]{2}{*}{ English Name } & \multicolumn{4}{|c|}{ Number of Responses } \\
\hline & & & Independent & Idiosyncratic & Blank & Illegible \\
\hline CUCHILLO & 130 & KNIFE & 85 & 47 & 0 & 3 \\
\hline CUENCO & 34 & BOWL & 121 & 77 & 0 & 5 \\
\hline CHALECO & 247 & VEST & 135 & 85 & 1 & 5 \\
\hline CHAQUETA & 125 & JACKET & 112 & 62 & 1 & 3 \\
\hline DEDAL & 230 & THIMBLE & 57 & 36 & 0 & 1 \\
\hline DEDO & 88 & FINGER & 78 & 48 & 0 & 2 \\
\hline DESTORNILLADOR & 199 & SCREWDRIVER & 101 & 57 & 0 & 2 \\
\hline ELEFANTE & 84 & ELEPHANT & 90 & 51 & 0 & 3 \\
\hline ENCHUFE & 177 & PLUG & 82 & 49 & 0 & 3 \\
\hline ESCALERA & 131 & LADDER & 109 & 69 & 0 & 4 \\
\hline ESCOBA & 37 & BROOM & 51 & 24 & 0 & 0 \\
\hline ESCRITORIO & 72 & DESK & 87 & 50 & 0 & 0 \\
\hline ESPÁRRAGO & 11 & ASPARAGUS & 132 & 85 & 1 & 5 \\
\hline ESTRELLA & 217 & STAR & 87 & 52 & 0 & 3 \\
\hline FALDA & 205 & SKIRT & 98 & 53 & 1 & 2 \\
\hline FLAUTA & 92 & FLUTE & 100 & 54 & 0 & 1 \\
\hline FLECHA & 8 & ARROW & 95 & 60 & 0 & 1 \\
\hline FLOR & 91 & FLOWER & 105 & 58 & 0 & 3 \\
\hline FOCA & 201 & SEAL & 116 & 63 & 0 & 4 \\
\hline FRESA & 220 & STRAWBERRY & 113 & 63 & 1 & 1 \\
\hline FRIGORÍFICO & 185 & REFRIGERATOR & 71 & 45 & 0 & 2 \\
\hline GAFAS & 105 & GLASSES & 87 & 57 & 0 & 3 \\
\hline GALLINA & 55 & CHICKEN & 63 & 37 & 0 & 1 \\
\hline GALLO & 191 & ROOSTER & 84 & 48 & 0 & 4 \\
\hline GATO & 49 & CAT & 140 & 84 & 2 & 5 \\
\hline GLOBO & 15 & BALLOON & 100 & 54 & 0 & 2 \\
\hline GORILA & 108 & GORILLA & 98 & 59 & 0 & 9 \\
\hline GORRA & 46 & CAP & 98 & 66 & 0 & 5 \\
\hline GUANTE & 106 & GLOVE & 98 & 61 & 0 & 6 \\
\hline GUITARRA & 111 & GUITAR & 120 & 76 & 0 & 6 \\
\hline GUSANO & 50 & CATERPILLAR & 117 & 74 & 1 & 7 \\
\hline НАCHA & 12 & AXE & 92 & 54 & 0 & 1 \\
\hline HELICÓPTERO & 120 & HELICOPTER & 93 & 51 & 2 & 5 \\
\hline HILO & 214 & SPOOL OF THREAD & 77 & 41 & 0 & 2 \\
\hline HOJA & 133 & LEAF & 83 & 55 & 0 & 1 \\
\hline HORMIGA & 5 & ANT & 128 & 75 & 2 & 1 \\
\hline IGLESIA & 57 & CHURCH & 128 & 86 & 0 & 5 \\
\hline INTERRUPTOR & 139 & LIGHT SWITCH & 51 & 34 & 0 & 3 \\
\hline JARRA & 175 & PITCHER & 54 & 33 & 0 & 4 \\
\hline JARRÓN & 246 & VASE & 70 & 52 & 0 & 2 \\
\hline JERSEY & 224 & SWEATER & 95 & 63 & 0 & 4 \\
\hline JIRAFA & 103 & GIRAFFE & 71 & 46 & 1 & 2 \\
\hline LABIOS & 141 & LIPS & 76 & 43 & 0 & 1 \\
\hline LÁMPARA & 132 & LAMP & 72 & 43 & 0 & 0 \\
\hline LÁPIZ & 168 & PENCIL & 91 & 44 & 0 & 2 \\
\hline LAZO & 33 & BOw & 104 & 58 & 1 & 4 \\
\hline LECHUGA & 137 & LETTUCE & 79 & 51 & 0 & 3 \\
\hline LEÓN & 140 & LION & 114 & 70 & 0 & 4 \\
\hline LEOPARDO & 136 & LEOPARD & 109 & 57 & 0 & 4 \\
\hline LIBRO & 30 & BOOK & 134 & 83 & 0 & 3 \\
\hline LIMA & 152 & NAIL FILE & 78 & 51 & 0 & 1 \\
\hline LIMÓN & 135 & LEMON & 76 & 49 & 0 & 5 \\
\hline LUNA & 146 & MOON & 101 & 66 & 0 & 0 \\
\hline LLAVE & 128 & KEY & 60 & 43 & 0 & 0 \\
\hline LLAVE INGLESA & 259 & WRENCH & 129 & 79 & 0 & 4 \\
\hline MAIZ & 66 & CORN & 104 & 68 & 0 & 4 \\
\hline MALETA & 221 & SUITCASE & 68 & 44 & 0 & 0 \\
\hline MANO & 115 & HAND & 124 & 74 & 0 & 4 \\
\hline MANOPLA & 144 & MITTEN & 95 & 56 & 0 & 2 \\
\hline MANZANA & 6 & APPLE & 102 & 57 & 0 & 2 \\
\hline MAPACHE & 183 & RACCOON & 109 & 62 & 2 & 3 \\
\hline MARIPOSA & 40 & BUTTERFLY & 111 & 68 & 0 & 2 \\
\hline MARTILLO & 114 & HAMMER & 89 & 53 & 0 & 5 \\
\hline MECEDORA & 188 & ROCKING CHAIR & 113 & 65 & 0 & 4 \\
\hline MELOCOTÓN & 164 & PEACH & 91 & 43 & 0 & 3 \\
\hline MESA & 226 & TABLE & 89 & 56 & 0 & 2 \\
\hline
\end{tabular}


APPENDIX (Continued)

\begin{tabular}{|c|c|c|c|c|c|c|}
\hline \multirow[b]{2}{*}{ Spanish Stimulus } & \multirow{2}{*}{$\begin{array}{l}\text { Picture } \\
\text { No. }\end{array}$} & \multirow[b]{2}{*}{ English Name } & \multicolumn{4}{|c|}{ Number of Responses } \\
\hline & & & Independent & Idiosyncratic & Blank & Illegible \\
\hline MOFETA & 206 & SKUNK & 81 & 52 & 1 & 11 \\
\hline MOLINO & 256 & WINDMILL & 58 & 32 & 0 & 3 \\
\hline MONO & 145 & MONKEY & 136 & 79 & 0 & 8 \\
\hline MONTAÑA & 148 & MOUNTAIN & 134 & 68 & 3 & 9 \\
\hline MOSCA & 93 & FLY & 112 & 60 & 0 & 4 \\
\hline мОто & 147 & MOTORCYCLE & 117 & 72 & 0 & 6 \\
\hline MUÑECA & 74 & DOLL & 107 & 63 & 0 & 2 \\
\hline MUÑECO DE NIEVE & 210 & SNOWMAN & 75 & 50 & 0 & 1 \\
\hline NARANJA & 158 & ORANGE & 99 & 49 & 0 & 5 \\
\hline NARIZ & 155 & NOSE & 101 & 58 & 0 & 4 \\
\hline NUBE & 62 & CLOUD & 89 & 56 & 0 & 1 \\
\hline OJO & 86 & EYE & 105 & 65 & 0 & 4 \\
\hline OREJA & 83 & EAR & 109 & 76 & 0 & 4 \\
\hline OSO & 21 & BEAR & 120 & 62 & 0 & 2 \\
\hline OVEJA & 202 & SHEEP & 86 & 50 & 0 & 5 \\
\hline PÁJARO & 28 & BIRD & 104 & 55 & 0 & 2 \\
\hline PAN DE MOLDE & 36 & BREAD & 96 & 55 & 0 & 2 \\
\hline PANTALÓN & 162 & PANTS & 119 & 73 & 0 & 3 \\
\hline PARAGUAS & 245 & UMBRELLA & 45 & 32 & 0 & 1 \\
\hline PATATA & 180 & РОТАТО & 107 & 62 & 1 & 2 \\
\hline PATÍN & 189 & ROLLER SKATE & 121 & 68 & 0 & 7 \\
\hline РАTO & 81 & DUCK & 107 & 64 & 1 & 5 \\
\hline PAVO REAL & 163 & PEACOCK & 121 & 76 & 0 & 4 \\
\hline PAYASO & 63 & CLOWN & 87 & 50 & 0 & 2 \\
\hline PEINE & 65 & $\mathrm{COMB}$ & 65 & 37 & 0 & 0 \\
\hline PELO & 113 & HAIR & 113 & 63 & 0 & 2 \\
\hline PELOTA & 14 & BALL & 77 & 48 & 0 & 2 \\
\hline PEONZA & 238 & TOP & 116 & 71 & 6 & 4 \\
\hline PERA & 166 & PEAR & 97 & 61 & 0 & 2 \\
\hline PERCHA & 116 & HANGER & 52 & 36 & 0 & 0 \\
\hline PERRO & 73 & DOG & 131 & 85 & 0 & 9 \\
\hline PEZ & 89 & FISH & 77 & 46 & 0 & 2 \\
\hline PIANO & 171 & PIANO & 110 & 65 & 0 & 3 \\
\hline PIE & 94 & FOOT & 82 & 44 & 0 & 4 \\
\hline PIMIENTO & 170 & PEPPER & 98 & 55 & 0 & 1 \\
\hline PINCEL & 161 & PAINTBRUSH & 51 & 30 & 0 & 3 \\
\hline PINGÜINO & 169 & PENGUIN & 83 & 51 & 0 & 5 \\
\hline PINZA & 61 & CLOTHESPIN & 78 & 54 & 0 & 1 \\
\hline PIÑA & 173 & PINEAPPLE & 116 & 66 & 3 & 4 \\
\hline PIPA & 174 & PIPE & 98 & 62 & 0 & 2 \\
\hline PISTOLA & 112 & GUN & 91 & 55 & 0 & 6 \\
\hline PLANCHA & 123 & IRON & 96 & 62 & 0 & 1 \\
\hline PLÁTANO & 16 & BANANA & 84 & 48 & 0 & 1 \\
\hline РОМО & 77 & DOORKNOB & 79 & 61 & 5 & 3 \\
\hline PUERTA & 76 & DOOR & 83 & 49 & 0 & 5 \\
\hline PURO & 58 & CIGAR & 118 & 77 & 0 & 4 \\
\hline RANA & 100 & FROG & 74 & 43 & 0 & 0 \\
\hline RAQUETA & 229 & TENNIS RACKET & 54 & 40 & 0 & 3 \\
\hline RATÓN & 149 & MOUSE & 114 & 75 & 0 & 10 \\
\hline REGADERA & 251 & WATERING CAN & 42 & 23 & 0 & 0 \\
\hline REGLA & 192 & RULER & 112 & 63 & 0 & 4 \\
\hline RELOJ & 250 & WATCH & 69 & 43 & 0 & 1 \\
\hline RINOCERONTE & 186 & RHINOCEROS & 92 & 60 & 0 & 3 \\
\hline RODILLO & 190 & ROLLING PIN & 100 & 60 & 0 & 1 \\
\hline RUEDA & 254 & WHEEL & 83 & 50 & 0 & 5 \\
\hline SALERO & 194 & SALTSHAKER & 93 & 55 & 0 & 2 \\
\hline SALTAMONTES & 110 & GRASSHOPPER & 114 & 81 & 0 & 7 \\
\hline SANDÍA & 252 & WATERMELON & 59 & 29 & 1 & 2 \\
\hline SANDWICH & 195 & SANDWICH & 81 & 48 & 0 & 0 \\
\hline SARTÉN & 101 & FRYING PAN & 59 & 28 & 0 & 1 \\
\hline SERPIENTE & 209 & SNAKE & 140 & 87 & 0 & 5 \\
\hline SETA & 150 & MUSHROOM & 93 & 56 & 0 & 2 \\
\hline SIERRA & 196 & SAW & 101 & 63 & 0 & 1 \\
\hline SILBATO & 255 & WHISTLE & 84 & 51 & 0 & 3 \\
\hline SILLA & 53 & CHAIR & 80 & 43 & 0 & 2 \\
\hline SOBRE & 85 & ENVELOPE & 44 & 26 & 0 & 6 \\
\hline
\end{tabular}


APPENDIX (Continued)

\begin{tabular}{|c|c|c|c|c|c|c|}
\hline \multirow[b]{2}{*}{ Spanish Stimulus } & \multirow{2}{*}{$\begin{array}{c}\text { Picture } \\
\text { No. }\end{array}$} & \multirow[b]{2}{*}{ English Name } & \multicolumn{4}{|c|}{ Number of Responses } \\
\hline & & & Independent & Idiosyncratic & Blank & Illegible \\
\hline SOFÁ & 67 & $\mathrm{COUCH}$ & 65 & 31 & 0 & 4 \\
\hline SOL & 222 & SUN & 76 & 46 & 0 & 3 \\
\hline SOMBRERO & 118 & HAT & 129 & 83 & 1 & 5 \\
\hline TABLA DE PLANCHAR & 124 & IRONING BOARD & 88 & 58 & 1 & 2 \\
\hline TABURETE & 218 & STOOL & 86 & 45 & 0 & 4 \\
\hline TAMBOR & 80 & DRUM & 131 & 77 & 0 & 2 \\
\hline TARTA & 42 & CAKE & 72 & 42 & 0 & 2 \\
\hline TAZA & 70 & CUP & 65 & 41 & 0 & 0 \\
\hline TELÉFONO & 227 & TELEPHONE & 113 & 74 & 1 & 9 \\
\hline TELEVISIÓN & 228 & TELEVISION & 141 & 80 & 2 & 5 \\
\hline TENEDOR & 97 & FORK & 60 & 37 & 0 & 2 \\
\hline TETERA & 127 & KETTLE & 81 & 52 & 0 & 0 \\
\hline TIGRE & 233 & TIGER & 128 & 86 & 0 & 2 \\
\hline TIJERAS & 197 & SCISSORS & 92 & 61 & 0 & 2 \\
\hline TOCADISCOS & 184 & RECORD PLAYER & 69 & 41 & 1 & 3 \\
\hline TOMATE & 236 & TOMATO & 91 & 58 & 0 & 1 \\
\hline TORNILLO & 198 & SCREW & 97 & 51 & 0 & 4 \\
\hline TOSTADOR & 234 & TOASTER & 77 & 49 & 0 & 1 \\
\hline TREN & 240 & TRAIN & 122 & 74 & 0 & 3 \\
\hline TRINEO & 207 & SLED & 55 & 36 & 0 & 4 \\
\hline TROMBÓN & 99 & FRENCH HORN & 89 & 54 & 0 & 9 \\
\hline TROMPETA & 243 & TRUMPET & 120 & 71 & 0 & 6 \\
\hline TUERCA & 156 & NUT & 107 & 64 & 0 & 0 \\
\hline UVAS & 109 & GRAPES & 87 & 48 & 1 & 7 \\
\hline VACA & 68 & COW & 69 & 33 & 0 & 5 \\
\hline VALLA & 87 & FENCE & 130 & 70 & 0 & 4 \\
\hline VASO & 104 & GLASS & 52 & 27 & 0 & 2 \\
\hline VELA & 44 & CANDLE & 94 & 52 & 0 & 4 \\
\hline VENTANA & 257 & WINDOW & 93 & 51 & 0 & 3 \\
\hline VESTIDO & 78 & DRESS & 101 & 52 & 0 & 1 \\
\hline VIOLÍN & 248 & VIOLIN & 135 & 85 & 0 & 8 \\
\hline ZANAHORIA & 48 & CARROT & 84 & 45 & 0 & 3 \\
\hline ZAPATO & 204 & SHOE & 108 & 56 & 0 & 2 \\
\hline ZORRO & 98 & FOX & 156 & 102 & 1 & 7 \\
\hline
\end{tabular}

Note-Picture No. is the identification number of the picture corresponding to the stimulus in Snodgrass and Vanderwart (1980). English name is the most frequent denomination of the picture in English in Snodgrass and Vanderwart.

(Manuscript received December 12, 2003;

revision accepted for publication June 21, 2004.) 